\title{
sciendo

\section{Survey Research of Selected Issues the Sick Building Syndrome (SBS) in an Office Building}

\author{
Katarzyna GLADYSZEWSKA-FIEDORUK* \\ Bialystok University of Technology, Wiejska 45E, Bialystok, 15-351, Poland
}

\begin{abstract}
The reason why the Sick Building Syndrome appears is not enough flow of the fresh air going into the rooms. It could cause various ailments, although it is difficult to determine their source and the symptoms disappear soon after leaving the building. The paper discusses the sources of the indoor air pollution, symptoms of Sick Building Syndrome and shows the solutions how to avoid the phenomena of "sick" buildings. In addition, the results of questionnaire surveys on the well-being of employees, which were carried out in an office building in Warsaw, were presented. The vast majority of respondents in the building spend 8 hours, during which their well-being deteriorates. More than half of the respondents felt typical symptoms of the Sick Building Syndrome. To avoid the formation of "sick building" should be replaced regularly air. The exchange method is not important.
\end{abstract}

Keywords - pollution of indoor environmental; Sick Building Syndrome; survey

\section{INTRODUCTION}

In the pursuit of energy efficiency, we often forget about the ventilation of rooms. Currently, up to $80 \%$ (some sources even provide $90 \%$ ) of energy expenditure are related to ventilation [1]-[3]. The exchange of air in rooms is necessary and it does not matter how it will take place [4]. We can exchange air in a natural way - contrary to appearances, causing the greatest energy losses [5]-[8] or fully automated mechanical with heat recovery, significantly more expensive during investment, but more energy-efficient during operation [7], [9].

The ventilation and air conditioning system itself can be a source of indoor air pollution [2], [7], [10], [11]. In addition to the development of microorganisms inside the ducts are more prosaic pollution like dust.

A ,sick building” is when $30 \%$ of all users complain about the internal environment, while experiencing various types of ailments [12]. The ailments are stronger the longer people are in the "sick" room. It isn't possible to specify what causes these disabilities. Unpleasant symptoms are mainly associated with poor air quality in the room [13], [14]. After leaving the "sick building", the discomfort disappears in a short time.

\subsection{Sources of Air Pollution in Rooms}

The source of air pollution in the room may be: living organisms (e.g. people, fungi) [15]-[17] building materials and elements of interior design (e.g. furniture and linings, for the production of which solvents, impregnates, compounds emitted by painting paints or asbestos, televisions, computers), ventilation and air conditioning systems (e.g. microorganisms living in non-cleaned

\footnotetext{
* Corresponding author.

E-mail address: k.gladyszewska@pb.edu.pl 
ventilation ducts [13], [14]) - Fig. 1, external air (e.g. chemical and biological pollution), self-use of premises (e.g. smoking tobacco, cooking).

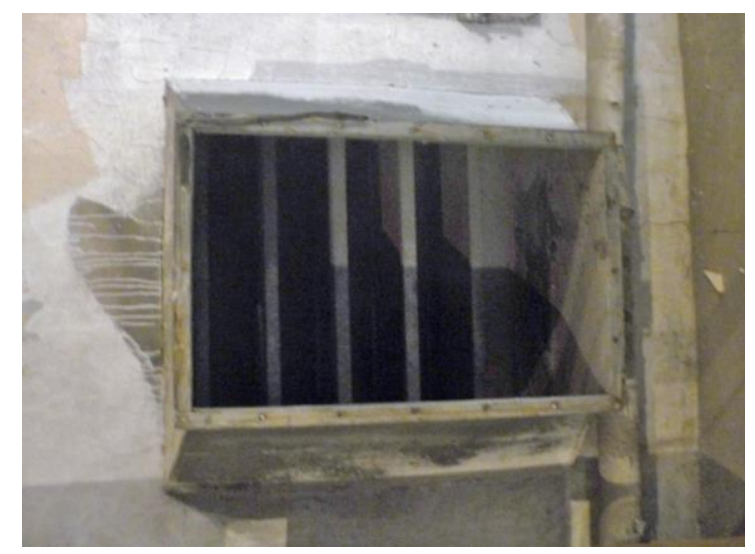

Fig. 1. Dust chamber with a filter section (own collection).

\subsection{Symptoms of a Sick Building Syndrome}

The symptoms of the Sick Building Syndrome experienced by people are primarily [7], [18], [19]: headache and dizziness, fainting, nausea, fatigue, allergic symptoms, irritation of mucous membranes: irritation of eyes, nose and throat, dry cough, drying and flaking of the skin, difficulty concentrating, difficult breathing, hypersensitivity to odours.

A "sick building" not only harms people staying in it. A building to which a too small stream of ventilation air is being destroyed. Mushrooms, molds and microorganisms thrive in "sick buildings" [13], [17] attack potted plants, cause degradation of building walls (Fig. 2) and their equipment [7], [20], [21]. The moisture accumulated in the room, at elevated temperature, is not only a breeding ground for fungi and molds, it also destroys building partitions and building equipment itself (Fig. 3).

The aim of the article is to analyse surveys conducted to determine whether the building being tested is a "sick building". The presented research, in summary, leads to the need to prepare procedures for determining "sick buildings". Such procedures are not specified in the applicable standards [22], [23].

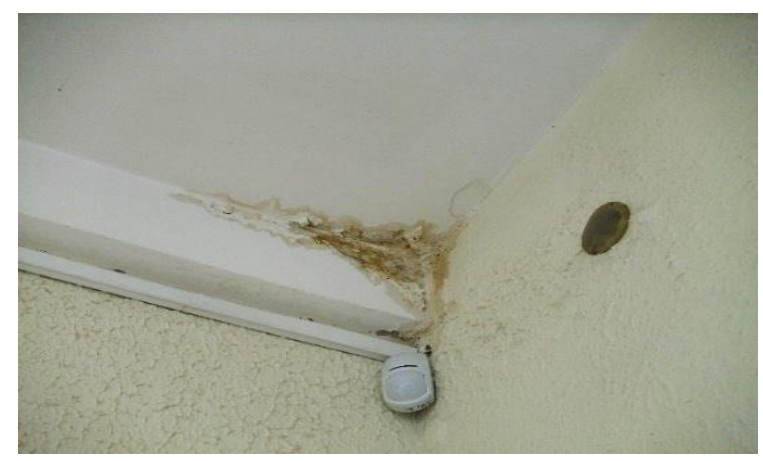

Fig. 2. Mushroom and mold on the building wall (own collection). 


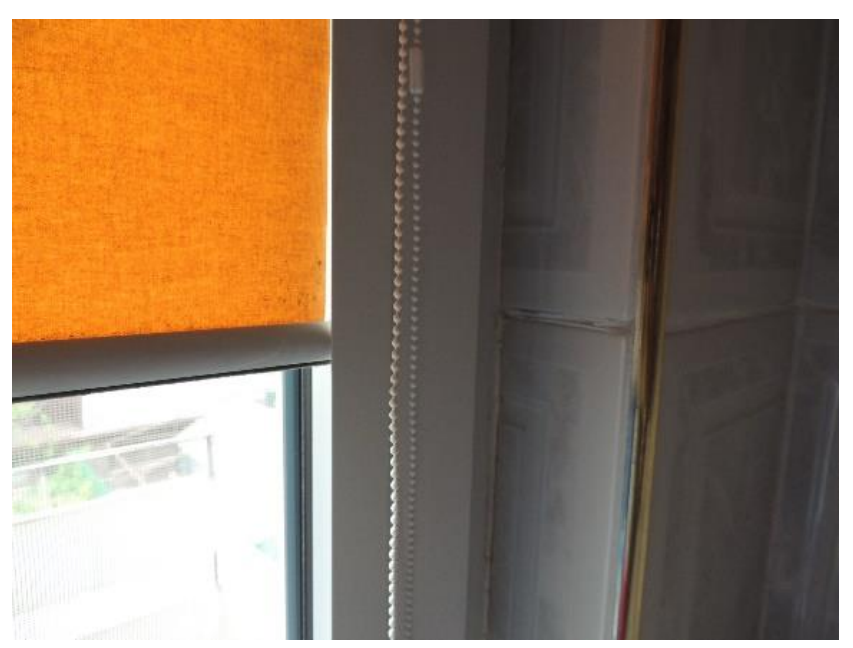

Fig. 3. Mushroom on building equipment (own collection).

\section{SURVEY - Methodology AND RESUltS}

Survey research was carried out in Warsaw. The office building employs 200 people, on one floor, in various rooms, 50 people work. There is collective ventilation in the building, in each room there is a grille. In the rooms there is no control of the stream size, temperature value. In some rooms there are non-opening windows.

Temperature, humidity, $\mathrm{CO}_{2}$ concentration, PM10, PM2.5 were also measured. The measurement results are given in Table 1.

TABLE 1. PARAMETERS OF THE INDOOR AIR ON ANALYSED BUILDING

\begin{tabular}{llllll}
\hline Windows & Temperature, ${ }^{\circ} \mathrm{C}$ & Humidity, $\%$ & $\begin{array}{l}\mathrm{CO}_{2} \text { concentration, } \\
\mathrm{ppm}\end{array}$ & $\mathrm{PM} 10, \mu \mathrm{g} / \mathrm{m}^{3}$ & $\mathrm{PM} 2.5, \mu \mathrm{g} / \mathrm{m}^{3}$ \\
\hline $\begin{array}{l}\text { Non-opening } \\
\text { windows }\end{array}$ & 24.7 & 65 & 1672 & 84 & 48 \\
$\begin{array}{l}\text { Opening } \\
\text { windows }\end{array}$ & 23 & 48 & 1221 & 51 & 27 \\
\hline
\end{tabular}

In analysed office building indoor air temperature was recorded in range from $23{ }^{\circ} \mathrm{C}$ to $24.7{ }^{\circ} \mathrm{C}$. In some people's opinion and standards [22] it was too high. Relative humidity was in range $48 \%$ to $65 \%$ was high according to [22]. Carbon dioxide concentration exceeded recommended $1000 \mathrm{ppm}$ [22] reached 1221 to $1672 \mathrm{ppm}$. PM10 was in range 51 to $84 \mu \mathrm{g} / \mathrm{m}^{3}$ and exceed the acceptable standards [24], [25]. PM2.5 was in range 27 to $48 \mu \mathrm{g} / \mathrm{m}^{3}$ and exceed the acceptable standards [25]. 


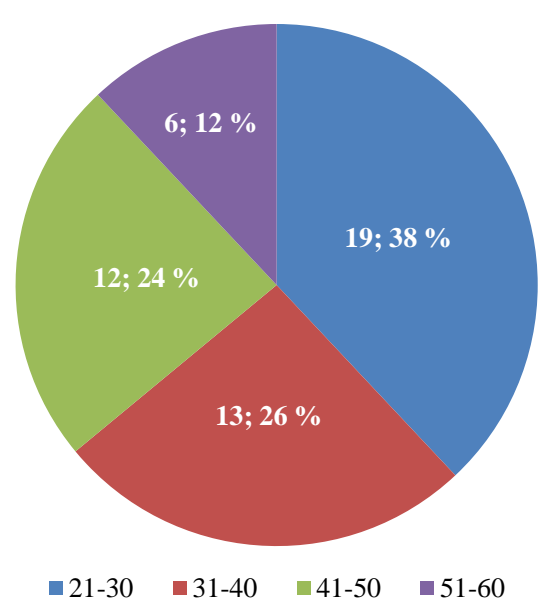

Fig. 4. Age of respondents.

The age of respondents is presented in Fig. 4. The largest group of respondents were people up to 30 years old -19 people, the smallest oldest, aged 51-60 - 6 people. The study was attended by 28 people with humanistic education and 22 people with technical education. The respondents are 30 women and 20 men.

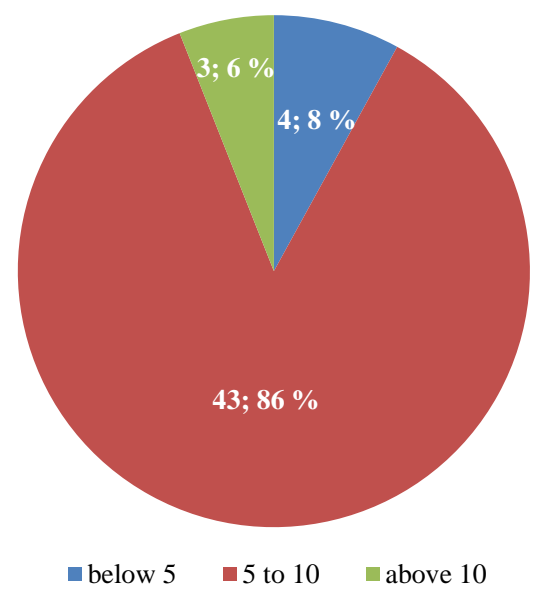

Fig. 5. The answer to the question: How many hours a day do you spend at work?

To the question: How many hours a day do you spend at work? Most of the respondents - 43 people, responded that 5 to 10 hours (Fig. 5).

While constructing the survey, the questionnaires presented in the literature [26]-[28] were used. 50 people agreed to participate in the study.

The survey included the following questions:

- Age: up to $20 \square ; 21-30 \square ; 31-40 \square ; 41-50 \square ; 51-60 \square$; more than $61 \square$;

- Gender: $\mathrm{W} \square ; \mathrm{M} \square$;

- Education: Technical $\square$; Humanistic $\square$; 
- How many hours a day do you spend at work? Below $5 \square$; 5 to $10 \square$; above $10 \square$;

- Do you use ventilation/air conditioning at work? Yes $\square$; No $\square$;

- How do you care for indoor air?

- How do you feel immediately after leaving the office building? (several answers): I take a deep breath $\square$; My head hurts $\square$; My eyes are burning $\square$; My stomach hurts $\square$; I am dry in my throat $\square$; The joy that I leave this building $\square$; None of the above $\square$.

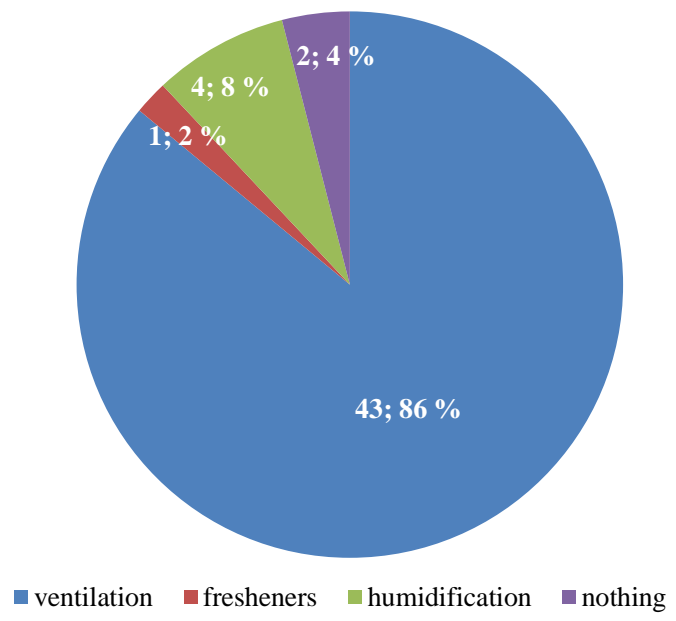

Fig. 6. Answers to the question: How do you care for air in the rooms?

I take a deep breath

My stomach hurts

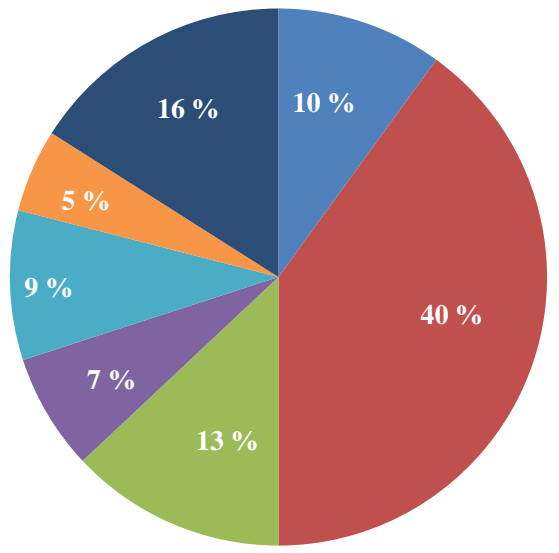

My head hurts

My eyes are burning

I'm dry in my throat
The joy that I leave this building

none of the above

Fig. 7. Answers to the question: How do you feel immediately after leaving the office building? 
36 respondents use ventilation or air conditioning, while 14 do not use. Answers to the question: How do you care for indoor air? there were only four (Fig. 6). The vast majority of respondents 43 people, air the room. To the question: How do you feel immediately after leaving the office? in response to which you could mark several answers. Respondents usually marked one or two responses (Fig. 7).

$39 \%$ of responses concerned headache, $13 \%$ indicated eye burning, $7 \%$ complained of abdominal pain and $9 \%$ of respondents complained of dry throat. $10 \%$ of people taking part in the survey take a deep breath from the building. $5 \%$ of respondents were satisfied that they were leaving the building, not indicating any complaints, while $17 \%$ of the respondents didn't feel any complaints.

\section{DisCuSSION}

Links between the Sick Building Syndrome and health presents many publications [2], [9], [12], [17], [28]-[30]. The close connection with the quality of internal air and with thermal comfort is presented in publications. Surprising is the statement of the Sick Building Syndrome in the research presented by Polizzi et al. [31], Vance and Weissfeld [32], Ulpiani [33], Ulpiani et al. [34] in which no questionnaire surveys were carried out. This raises the question: what was the basis of the Sick Building Syndrome? After all, by definition: A "sick building" is when $30 \%$ of all users complain about the internal environment, while experiencing various types of ailments. The fact that the internal conditions are bad isn't synonymous with the occurrence of the Sick Building Syndrome.

Many researchers avoid the term Sick Building Syndrome [2], [9], [10], [12], [13], [17], [25] because it is a very broad concept. Nevertheless, the phenomenon of the Syndrome of the Sick Building associate's human health with the internal environment. Therefore, procedures should be developed to clearly determine whether the building is sick or healthy. Similar to the procedures determining the energy efficiency of buildings [35], [36].

The work focused on the reception of internal air by the surveyed. The reason is that the average person isn't able to identify causes such as the number of microorganisms in the internal environment, the amount of electromagnetic radiation, or the amount of chemicals in the room coming from external or internal air or derived from building materials and building equipment.

In the presented study, $39 \%$ of respondents consciously stated that after a day of work complaining about headaches, $13 \%$ indicated eye burning, $16 \%$ of people taking part in the study had other ailments. $17 \%$ of respondents didn't feel any complaints. It should be clearly stated that the building is sick. At least one of the recommended solutions should be used:

- Increasing the ventilation air stream and improving the efficiency of air distribution in the rooms, this reduces the concentration of pollutants;

- In rooms with high concentrations of pollutions, for example a printer or welding station or a kitchen where huge amounts of moisture are generated, it is necessary to install a local air pollutant;

- Removal of sources and causes of pollution, cleaning of places where dust and moisture collect, in particular elements of the ventilation system

\section{Conclusions}

To avoid the formation of "sick building" should be, among others, replaced regularly air. The method of air exchange is not important. You can use natural or mechanical ventilation. 
Summing up the survey, it should be noted that the vast majority of respondents in the building spend 8 hours, during which their well-being deteriorates. Most of the workers, despite installed mechanical ventilation, air the room, instinctively improving the parameters of the indoor air. More than half $(68 \%)$ of respondents felt typical symptoms of a Sick Building Syndrome. Therefore, the examined building is "sick".

Surveys must be the basis for the study of a Sick Building Syndrome. A standard set of questions applicable in all countries should be developed. Measuring procedures should be implemented depending on the external climate

\section{ACKNOWLEDGEMENT}

The research was carried out at the Bialystok University of Technology and financed from a subsidy provided by the Ministry of Science and Higher Education of Poland, from the resources of the WZ/WBiIŚ/4/2019 work and a project cofinanced by the European Regional Development Fund under the Podlaskie Voivodship Regional Operational Programme for the years 2007-2013 (5.2 and 1.1) and The Work Plan of scientific cooperation between Bialystok University of Technology and Vilnius College of Technologies and Design for years 2018-2020 within the following subject: The indoor air quality in teaching facilities

\section{REFERENCES}

[1] Basinska M., Koczyk H., Szczechowiak E. Sensitivity analysis in determining the optimum energy for residential buildings in Polish conditions. Energy and Building 2015:107:307-318. doi:10.1016/j.enbuild.2015.08.029

[2] Ferdyn-Grygierek J., Baranowski A. Internal environment in the museum building-Assessment and improvement of air exchange and its impact on energy demand for heating. Energy and Building 2015:92:45-54 doi:10.1016/j.enbuild.2015.01.033

[3] Krawczyk D. A. Analysis of energy consumption for heating in a residential house in Poland. Energy Procedia 2016:95:216-222. doi:10.1016/j.egypro.2016.09.053

[4] Vilcekova S., Meciarova L., Kridlova Burdova E., Katunska J., Kosicanova D., Doroudiani S. Indoor environmental quality of classrooms and occupants' comfort in a special education school in Slovak Republic. Building and Environment 2017:120:29-40. doi:10.1016/j.buildenv.2017.05.001

[5] Arendt K., Krzaczek M., Tejchman J. Influence of input data on airflow network accuracy in residential buildings with natural wind- and stack-driven ventilation. Building Simulation 2017:10(2):229-238. doi:10.1007/s12273-016-0320-5

[6] Mukhtar A., Ng K. C., Yusoff M. Z. Design optimization for ventilation shafts of naturally-ventilated underground shelters for improvement of ventilation rate and thermal comfort. Renewable Energy 2018:115:183-198. doi:10.1016/j.renene.2017.08.051

[7] Silva M. F., Maas S., de Souza H. A., Gomes A. P. Post-occupancy evaluation of residential buildings in Luxembourg with centralized and decentralized ventilation systems, focusing on indoor air quality (IAQ). Assessment by questionnaires and physical measurements. Energy and Building 2017:148:119-127. doi:10.1016/j.enbuild.2017.04.049

[8] Gil-Baez M., Barrios-Padura A., Molina-Huelva M., Chacartegui R. Natural ventilation systems in 21st-century for near zero energy school buildings. Energy 2017:137:1186-1200. doi:10.1016/j.energy.2017.05.188

[9] Sekhar S. C., Goh S. E. Thermal comfort and IAQ characteristics of naturally/mechanically ventilated and air-conditioned bedrooms in a hot and humid climate. Building and Environment 2011:46:1905-1916. doi:10.1016/j.buildenv.2011.03.012

[10] Wang Z., Xue Q., Ji Y., Yu Z. Indoor environment quality in a low-energy residential building in winter in Harbin. Building and Environment 2018:135:194-201. doi:10.1016/j.buildenv.2018.03.012

[11] Krawczyk D. A., Wądołowska B. Analysis of indoor air parameters in an education building. Energy Procedia 2018:147:96-103. doi:10.1016/j.egypro.2018.07.038

[12] Johnson D. L., Lynch R. A., Floyd E. L., Wang J., Bartels J. N. Indoor air quality in classrooms: Environmental measures and effective ventilation rate modeling in urban elementary schools. Building and Environment 2018:136:185-197. doi:10.1016/j.buildenv.2018.03.040

[13] Teleszewski T. J. The Viscous Dissipation Effect in a Regular Polygonal Duct for H2 Boundary Conditions. IOP Conference Series: Materials Science and Engineering 2017:269:012038. doi:10.1088/1757-899X/269/1/012038 
[14] Teleszewski T. J., Sorko S. A. Effect of viscous dissipation on forced convection for laminar flow through a straight regular polygonal duct using BEM method. International Journal of Numerical Methods for Heat and Fluid Flow 2018:28(1):220-238. doi:10.1108/HFF-09-2017-0371

[15] Marć M., Śmiełowska M., Namieśnik J., Zabiegała B. Indoor air quality of everyday use spaces dedicated to specific purposes-a review. Environmental Science and Pollution Research 2018:25:2065-2082. doi:10.1007/s11356-017-0839-8

[16] Skowron K., Grudlewska K., Kwiecińska-Piróg J., Gryń G., Śrutek M., Gospodarek-Komkowska E. Efficacy of radiant catalytic ionization to reduce bacterial populations in air and on different surfaces. Science of the Total Environment 2018:610-611:111-120. doi:10.1016/j.scitotenv.2017.08.032

[17] Śmiełowska M., Marć M., Zabiegała B. Indoor air quality in public utility environments-a review. Environmental Science and Pollution Research 2017:24:11166-11176. doi:10.1007/s11356-017-8567-7

[18] Földváry V., Bekö G., Langer S., Arrhenius K., Petráš D. Effect of energy renovation on indoor air quality in multifamily residential buildings in Slovakia. Building and Environment 2017:122:363-372. doi:10.1016/j.buildenv.2017.06.009

[19] Bourdakis E., Simone A., Olesen B. W. An experimental study of the effect of different starting room temperatures on occupant comfort in Danish summer weather. Building and Environment 2018:136:269-278. doi:10.1016/j.buildenv.2018.03.046

[20] Ickiewicz I. Building thermomodernization and reducing air pollution. Ecological Chemistry and Engineering $S$ 2013:20(4):805-816. doi:10.2478/eces-2013-0056

[21] Ickiewicz I. Ecological and economic aspects of modernizing district heating systems in north-eastern Poland. Ecological Chemistry and Engineering S 2011:18(4):429-443.

[22] PN-EN 13779:2008 Ventilation for non-residential buildings. Performance requirements for ventilation and room-conditioning systems.

[23] PN-EN 15251:2007 Indoor environmental input parameters for design and assessment of energy performance of buildings - addressing indoor air quality, thermal environment, lighting and acoustics.

[24] Rogulski M. Indoor PM10 concentration measurements using low-cost monitors in selected locations in Warsaw. Energy Procedia 2018:147:137-144.

[25] Rogulski M. Low-cost PM monitors as an opportunity to increase the spatiotemporal resolution of measurements of air quality. Energy Procedia 2017:128:437-444. doi:10.1016/j.egypro.2017.09.026

[26] Gładyszewska-Fiedoruk K. Ocena powszechności stosowania systemów wentylacji [The assessment of ventilating systems popularity]. Technika Chłodnicza i Klimatyzacyjna 2014:3:117-119

[27] Musa A. R., Abdullah N. A. G., Che-Ani A. I., Tawil N. M., Tahir M. M. Temperature Analysis for Indoor Environmental Quality (IEQ) of UKM Architecture Studio. Procedia - Social and Behavioral Sciences 2012:60:575581. doi:10.1016/j.sbspro.2012.09.425

[28] Sun Ch., Guo Y., Huang Ch., Zou Z., Hu Y., Liu W. Associations of Building Characteristics and Lifestyle Behaviors with Allergic Disease for Adults in Shanghai: from a Cross-sectional Survey. Procedia Engineering 2017:205:11301137. doi:10.1016/j.proeng.2017.10.182

[29] Mac Naughton P., Satish U., Cedeno Laurent J. G., Flanigan S., Allen J. G. The impact of working in a green certified building on cognitive function and health. Building and Environment 2017:114:178-186. doi:10.1016/j.buildenv.2016.11.041

[30] Othman M., Latif M. T., Mohamed A. F. Health impact assessment from building life cycles and trace metals in coarse particulate matter in urban office environments. Ecotoxicology and Environmental Safety 2018:148:293-302. doi:10.1016/j.ecoenv.2017.10.034

[31] Polizzi V., Adams A., Picco A. M., Adriaens E., Lenoir J., Van Peteghem C., De Saeger S., De Kimpe N. Influence of environmental conditions on production of volatiles by Trichoderma atroviride in relation with the sick building syndrome. Building and Environment 2011:46(4):945-954. doi:10.1016/j.buildenv.2010.10.024

[32] Vance P. H., Weissfeld A. S. The controversies surrounding sick building syndrome. Clinical Microbiology Newsletter 2007:29(10):73-76. doi:10.1016/j.clinmicnews.2007.04.007

[33] Ulpiani G. Overheating phenomena induced by fully-glazed facades: Investigation of a sick building in Italy and assessment of the benefits achieved via fuzzy control of the AC system. Solar Energy 2017:158:572-594. doi:10.1016/j.solener.2017.10.024

[34] Ulpiani G., Benedettelli M., di Perna C., Naticchia B. Overheating phenomena induced by fully-glazed facades: Investigation of a sick building in Italy and assessment of the benefits achieved via model predictive control of the AC system. Solar Energy 2017:157:830-852. doi:10.1016/j.solener.2017.09.009

[35] Spiru P., Simona P. L. A review on interactions between energy performance of the buildings, outdoor air pollution and the indoor air quality. Energy Procedia 2017:128:179-186. doi:10.1016/j.egypro.2017.09.039

[36] Miezis M., Zvaigznitis K., Stancioff N., Soeftestad L. Climate Change and Buildings Energy Efficiency - the Key Role of Residents. Environmental and Climate Technologies 2016:17(1):30-43. doi:10.1515/rtuect-2016-0004 